\title{
An Effort of Mutation Breeding by Oryzalin and Gamma Rays on Wild Raspberry (Rubus sp.) in Cibodas Botanical Garden
}

\author{
${ }^{\otimes}$ Muhammad Imam Surya, Lily Ismaini, Destri, Suluh Normasiwi
}

DOI: 10.15294/biosaintifika.v8i3.6559

Cibodas Botanical Garden, Indonesian Institute of Sciences, Indonesia

\section{History Article}

Received 17 July 2016 Approved 15 October 2016 Published 24 December 2016

\section{Keywords:}

Rubus; mutation breeding; chemical and physical mutagens

\begin{abstract}
Currently, Cibodas Botanical Garden (CBG) has a domestication programme of wild raspberries (Rubus sp.) from Indonesia mountain forest. One of the activities in the domestication programme is fruit breeding. In order to improve the quality of wild raspberry, two mutagens i.e. chemical (oryzalin) and physical (gamma rays) mutagens were used in the breeding programme. Moreover, seed of wild raspberries from the collection of CBG were used in the programme of mutation breeding. The results showed that each species of wild raspberries has different response on the mutagen. Percentage of seed germination were affected by mutagen of oryzalin and gamma rays. Rubus fraxinifolius and Rubus rosifolius seeds were still able to germinate after treated by $100 \mu \mathrm{M}$ of oryzalin. In the other hand, with increase in radiation above 300 Gy a reduction in percentage of germination was observed in M1 generation of Rubus lineatus and Rubus chrysophyllus.
\end{abstract}

\section{How to Cite}

Surya, M. I., Ismaini, L., Destri, D. \& Normasiwi, S. (2016). An Effort of Mutation Breeding by Oryzalin and Gamma Rays on Wild Raspberry (Rubus spp.) in Cibodas Botanical Garden. Biosaintifika: Journal of Biology \& Biology Education, 8(3), 331-335.

(C) 2016 Universitas Negeri Semarang $\square$ Correspondence Author:

PO. BOX. 19 SDL Cipanas-Cianjur 43253, West Java

E-mail: muhammad.imam.surya@lipi.go.id
p-ISSN 2085-191X

e-ISSN 2338-7610 


\section{INTRODUCTION}

Cibodas Botanical Garden (CBG) or Bergtuin te Tjibodas, part of Indonesian Institute of Sciences, was established on April $11^{\text {th }}, 1852$ (Suryana \& Widyatmoko, 2013). Cibodas Botanical Garden, an institution for ex situ plant conservation, provides breeders with the basic resources, i.e. genetic variation from wild species for breeding purposes. Based on International Agenda for Botanic Gardens in Conservation (2000), some of major activities of botanic gardens include; conservation biology, environmental education programmes, ethnobiology research, herbarium studies and plant taxonomy, horticultural research and training, laboratory research including in vitro plant cultivation, seed store and tissue banking, tourism, and many more.

Botanical garden has an important role in crop improvement. Moreover, in the domestication process, the useful species were chosen and cultivated, and improved by continuous selection. Through that process, the genetic improvement of those species have been achieved by selection, first from natural seedling population and then from the field that continued unique genotype fixed by vegetative propagation (Lestari \& Surya, 2016). Since 2014, wild Rubus domestication programme was ongoing projects in CBG. This project was focusing on utilizing and developing wild Rubus from Indonesian mountain forests.

Plant breeding is a deliberate effort by humans to nudge nature, with respect to the heredity of plants, to an advantage. The changes made in plants are permanent and heritable (Acquaah, 2012). Plant breeding is the purposeful manipulation of plant species in order to create desired genotypes and phenotypes for specific purposes. Plant breeding can be accomplished through many different techniques ranging from simply selecting plants with desirable characteristics for propagation, to more complex molecular techniques. Several techniques such as hybridization, mutation, selection, molecular marker were applied in the plant breeding programme.

Wild raspberries (Rubus sp.) are collection of Cibodas Botanical Garden (CBG). Currently, CBG has been collected 12 species i.e. $R$. accuminatisimus, $R$. alceifolius, $R$. alpestris, $R$. chrysophyllus, $R$. ellipticus, $R$. elongatus, $R$. fraxinifolius, $R$. lineatus, $R$. moluccanus, $R$. rosifolius, $R$. pyrifolius and Rubus sp. (Surya et al., 2015). Raspberries of Indonesian mountain forest is highly known by its potential as fresh fruits, beverage raw materials, and medicinal plants (Normasiwi \& Surya, 2016). Utilization and development of wild rasp- berry as a fruit crop becomes a CBG programme. An improvement of fruit quality was conducted by three steps, i.e. selection, mutation breeding, and cultivation. At present, we are using four species of Rubus ( $R$. fraxinifolius, $R$. rosifolius, $R$. chrysophyllus and $R$. lineatus) in the fruit breeding, selection, and cultivation programmes.

Mutation is an approach for species improvement and development. Several mutagen were used in the mutation breeding programme, such as physical and chemical mutagens (Medina et al., 2004), to improve and develop a Rubus species. In order to domesticate and develop wild raspberries from Indonesian Mountain Forests, this activity is aimed to improve the genetic variance of wild raspberry for cultivation purposes through mutation breeding.

\section{METHODS}

The research was conducted in the laboratory and greenhouse of Cibodas Botanical Garden-Indonesian Institute of Sciences (LIPI), West Java, in 2014-2015. Plant material were used in this research are seeds from four species of wild raspberries of CBG collection i.e. $R$. rosifolius, $R$. chrysophyllus, $R$. fraxinifolius and $R$. lineatus. Seeds were obtained from mature fruit. Induction of mutation Rubus spp. was divided into two different types of mutagens, i.e. oryzalin and gamma rays.

$R$. fraxinifolius and $R$. rosifolius seeds were subjected to chemical mutagen treatments by oryzalin. Each of this species obtained different concentration of oryzalin. $R$. fraxinifolius used three consentration of oryzalin $(50 \mu \mathrm{M}, 100 \mu \mathrm{M}$, and control) and two levels of time to submersion of seeds ( 6 and 24 hours). In other hand, $R$. rosifolius used eleven consentration of oryzalin $(0 \mu \mathrm{M}, 10$ $\mu \mathrm{M}, 20 \mu \mathrm{M}, 30 \mu \mathrm{M}, 40 \mu \mathrm{M}, 50 \mu \mathrm{M}, 60 \mu \mathrm{M}, 70$ $\mu \mathrm{M}, 80 \mu \mathrm{M}, 90 \mu \mathrm{M}, 100 \mu \mathrm{M})$ and three levels of time to submersion of seeds (1, 6, 24 hours). The difference in this treatment based on the availability of seed and number of seeds when the study was conducted.

Application of gamma rays irradiation of Rubus spp. had been conducted at the Center for the Application of Isotopes and Radiation Technology, BATAN. Gamma rays with six doses (100 Gy, 200 Gy, 300 Gy, 400 Gy, 500 Gy, and control) were subjected to the seed of $R$. lineatus, while seeds of $R$. chrysophyllus used eleven doses of gamma ray (50 Gy, $100 \mathrm{~Gy}, 150 \mathrm{~Gy}, 200 \mathrm{~Gy}$, 250 Gy, 300 Gy, 350 Gy, 400 Gy, 450 Gy, 500 Gy)

Rubus spp's. seeds were germinated on wet tissue paper in a petridish. Percentage of germina- 
tion was recorded every weeks for three months. Moreover, around 12 weeks after germinate, the seedlings of Rubus were carefully removed from petridish. The root were cleaned from remaining tissue paper. Afterward, the seedlings were transfered to small individual pots $(10 \times 10 \mathrm{~cm})$, which containing of rice husk and compost (1:1).

Statistical analysis was used to analyze the data. Referring to the procedure of data analysis from Gomez \& Gomez (1995), all the data were expressed as the mean.

\section{RESULTS AND DISCUSSION}

\section{Mutation breeding on Rubus fraxinifolius}

Chemical mutagen, oryzalin, was subjected to the seed of $R$. fraxinifolius. Five combinations of oryzalin concentration and submersion time, i.e. $0 \mu \mathrm{M}$ in 0 hour (control), $50 \mu \mathrm{M}$ in 6 hour, $50 \mu \mathrm{M}$ in 24 hour, $100 \mu \mathrm{M}$ in 6 hour, and $100 \mu \mathrm{M}$ in 24 hour, were applied to seeds. Seed that had been treated by oryzalin was germinated in a petridish on wet tissue paper. Moreover, Figure 1 shows that germination percentage and survival of germination of $R$. fraxinifolius seed treated by oryzalin was higher than control. The highest of germination percentage was showed by the combination of 24 hours of submersion with $50 \mu \mathrm{M}$ of oryzalin $(75.76 \%)$ and 6 hours of submersion with $100 \mu \mathrm{M}$ of oryzalin (75.76 $\%)$. It showed that the higher levels of oryzalin concentration and the longer of submersion time were related to a germination percentage of $R$.

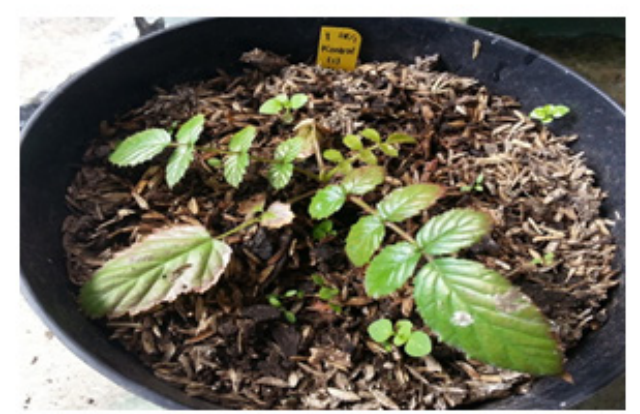

$$
\text { a. Control }
$$

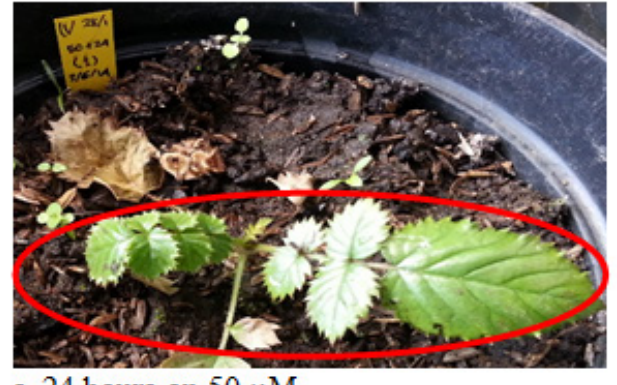

c. 24 hours on $50 \mu \mathrm{M}$ fraxinifolius seed. In the other hands, the percentage of survival germination after transplanting was showed by the combination of 6 hours of submersion with $50 \mu \mathrm{M}$ of oryzalin $(92.59 \%)$ and 24 hours of submersion with $100 \mu \mathrm{M}$ of oryzalin (92.59\%). Furthermore, Figure 2 shows the variation of leaf morphology in $R$. fraxinifoilus treated by oryzalin.

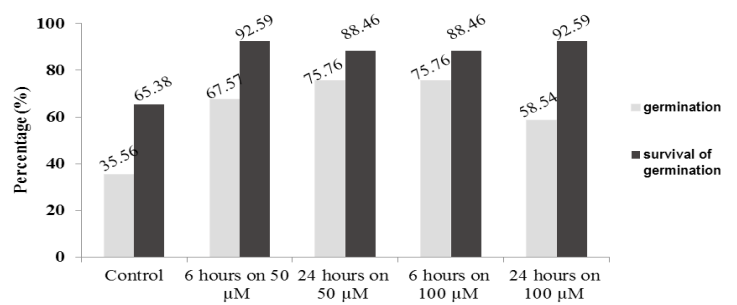

Figure 1. The effect of submersion time and doses of oryzalin on the germination percentage of Rubus fraxinifolius

\section{Mutation breeding on Rubus lineatus.}

Physical mutagen, gamma ray with six doses $(0,100,200,300,400,500)$, were subjected to the seed of $R$. lineatus. The result shows that the seeds of $R$. lineatus on doses 0, 100, 200 and 400 gray were still able to germinate. The highest percentage germination was showed in doses 100 gray (Figure 3).

\section{Mutation breeding on Rubus lineatus}

Physical mutagen, gamma ray with eleven doses $(0,50,100,150,200,250,300,350,400$, $450,500)$, were subjected to the seed of $R$. chryso-
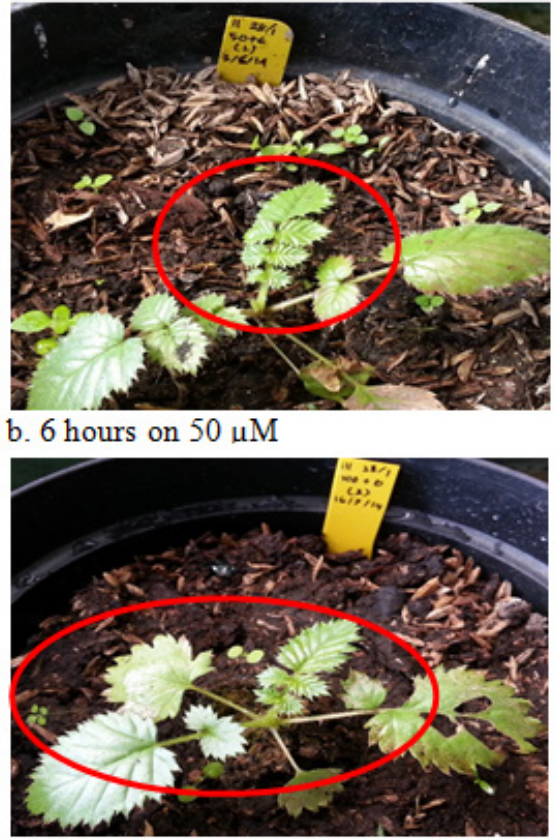

d. 6 hours on $100 \mathrm{uM}$

Figure 2. The leaf morphology variation of $R$. fraxinifoilus after treated by oryzalin 
phyllus. Except on the doses of 500 gray, germination percentage increased after treated by gamma ray. The highest of germination percentage was showed on 50 gray (Figure 4).

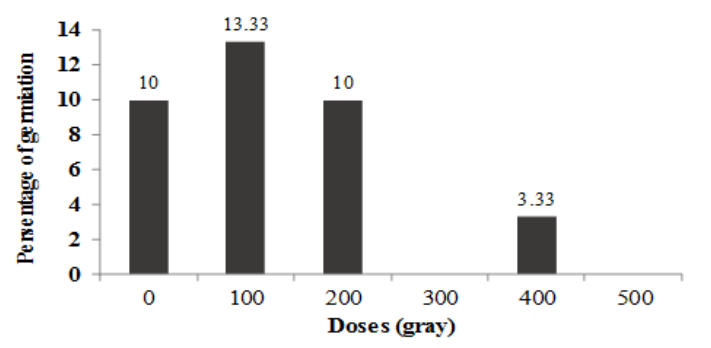

Figure 3. The effect of gamma ray irradiation on the germination percentage of Rubus lineatus

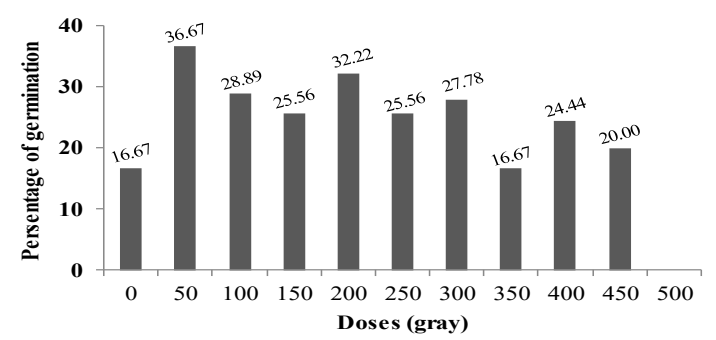

Figure 4. The effect of gamma ray irradiation on the germination percentage of Rubus chrysophyllus

Chemical mutagen, oryzalin with eleven doses $(0,10,20,30,40,50,60,70,80,90$, $100)$, were subjected to the seeds of $R$. rosifolius. Three levels of time (1, 6, 24 hours) were used to submersion the seed of $R$. rosifolius. The results showed that the highest of germination percentage was $98 \%$, while the seeds of $R$. rosifolius was soaked 24 hours in $30 \mu \mathrm{M}$ of oryzalin (Table 1 ). Moreover, after a year growth in a petridish, all germinated seeds were transplanted onto the pot in the plastic house. Base on survival percentage of $R$. rosifolius mutants, Table 2 shows that on 14 days after transplanting, mutants treated by higher concentration of oryzalin is more adap- table. The lowest survival percentage was mutant of $R$. rosifolius treated in $10 \mu \mathrm{M}$ of oryzalin.

Oryzalin and gamma rays affected the seed germination of $R$. fraxinifolius, $R$. lineatus, $R$. chrysophyllus, and $R$. rosifolius. The results showed that the increasing concentration of oryzalin was able to rise up the percentage germination of $R$. fraxinifolius (Figure 1) and $R$. rosifolius on 6 and 24 hours of submersion time (Tabel 2). The results seems unusual because generally the percentage of germination decreased as the concentration of mutagens increased. The reduction in germination may be due to genetic and physiological proses inhibited by the mutagens resulting in cell maturity (Umavathi \& Mullainathan, 2014). On the other side, Roychowdhury \& Tah (2011) reported that increasing the doses of colchicine were able to increase the germination percentage of Dianthus caryphyllus. Their result was in line with our experiment, which is the increasing concentration of oryzalin was able to increase the percentage germination of $R$. fraxinifolius and $R$. rosifolius. Furthermore, the range of gamma rays doses tested did not significantly affect the germination percentage of $R$. lineatus and $R$. chrysophyllus seeds. It is slightly different with certain studies performed on seeds of several species such as Withania samnifera (Bharathi et al., 2013), Citrus jambhiri (Sharma et al., 2013), Cajanus cajan (Ariraman et al., 2014) that a gradual decrease in seed germination from lower doses to higher doses of gamma rays were observed. In the other hand, Giovani et al. (2015) reported that the effect of gamma rays at 50, 100 and 200 Gy were able to increase seed germination of Rosa hybrida. Their results are in line with our experiment, which was the seed germination of $R$. lineatus increase in $50,100,150,200,250,300,400,450$ Gy and R. chrysophyllus in $100 \mathrm{~Gy}$.

Mutation induction is a part of domestication programme, in order to utilizing and cul-

Table 1. The effect of submersion time and doses of oryzalin on the percentage of Rubus rosifolius germination

\begin{tabular}{lccccccccccc}
\hline \multirow{2}{*}{$\begin{array}{l}\text { Submersion } \\
\text { Time }\end{array}$} & 0 & 10 & 20 & 30 & 40 & 50 & 60 & 70 & 80 & 90 & 100 \\
\hline 1 hours & 0 & 12 & 0 & 32 & 0 & 0 & 0 & 8 & 20 & 0 & 54 \\
6 hours & 4 & 14 & 56 & 22 & 58 & 38 & 93.33 & 14 & 78 & 74 & 54 \\
24 hours & 68 & 40 & 6 & 98 & 70 & 24 & 36 & 0 & 0 & 58 & 0 \\
\hline
\end{tabular}

Table 2. Survival percentage of $R$. rosifolius mutants on 14 days after transplanting.

\begin{tabular}{llllllllllll}
\hline Doses $(\mu \mathrm{M})(\%)$ & 0 & 10 & 20 & 30 & 40 & 50 & 60 & 70 & 80 & 90 & 100 \\
\hline Survival & 50 & 37.50 & 60 & 73.53 & 85.71 & 85.71 & 92 & 100 & 94.74 & 100 & 100 \\
\hline
\end{tabular}


tivating wild species. Mutagens have the ability to cause biological damage and it can be measured based on the seed germination and survival reduction in M1 generation (Umavathi \& Mullainathan, 2014). However, the percentage of seed germination was not always decreased with increasing doses/concentration of gamma rays and oryzalin in wild raspberries. In general, these results show that the mutagens have affected on seed germination. Moreover, small doses indicated that the mutagens have exerted a stimulus effect on seed germination, but in some cases the increasing doses have exerted an inhibitor effect.

Furthermore, oryzalin and gamma rays were able to affect the seed germination of wild raspberries. Mutagenic agents, such as oryzalin and gamma rays, with certain doses may be used to enhance seed vigor and increase the percentage of germination of wild raspberries

\section{CONCLUTION}

A preliminary study of mutation breeding is an effort to develop wild raspberry in Cibodas Botanical Garden. Both of mutagens, oryzalin and gamma rays affectedthe germination of $R u$ bus sp. Moreover, less than $100 \mu \mathrm{M}$ of oryzalin with 6 hours submersion time and less than 60 $\mu \mathrm{M}$ of oryzalin with 24 hours submersion time were the recommendation to treat the Rubus's seeds by oryzalin mutagen. In the other hand, the effective doses of gamma rays for Rubus's seeds were less than $300 \mathrm{~Gy}$.

\section{ACKNOWLEDGMENTS}

The authors would like to thank to Indonesian Institute of Sciences for financial support for wild Rubus domestication programme at Cibodas Botanical Garden through the programme of DIPA Tematik 2014 and 2015. We also thank to Center for Isotopes and Radiation Application - National Nuclear Energy Agency of Indonesia for their permission support to use irradiator gamma ray.

\section{REFERENCES}

Acquaah, G. (2012). Principles of plant genetics and breeding. Second eds. New Jersey: Willey Blackwell.

Ariraman, M., Gnanamurthy, S., Dhanavel, D., Bharathi, T., \& Murugan, S. (2014). Mutagenic effect on seed germination, seedling growth and seedling survival of pigeon pea (Cajanus cajan L.) Millsp). International Letters of Natural Sciences, 21, 41-49.

Bharathi, T., Gnanamurthy, S., Dhanavel, D., Murugan, S., \& Ariraman, M. (2013). Induced physical mutagenesis on seed germination, lethal dosage and morphological mutants of Ashwagandha (Withania somnifera (L.) Dunal). International Journal of Advanced Research, 1(5), 136-141.

Giovani, A., Scariot, V., Caser, M., Buttafava, A., Mansuino, A., Ghione, G. G., Savona, M., Sabatini, M. E., Carbonera, D., \& Balestrazzi, A. (2015). Mutation breeding using gamma rays to increase seed germination in Rosa hybrida. Acta Hort. 1087, 373-378.

Gomez, K. A., \& Gomez, A. A. (1995). Statistical procedure for agriculture research. Second eds. Translated by E. Sjamsuddin \& J.S. Baharsjah. Jakarta: Universitas Indonesia Press. 698 pp.

Lestari, R., \& Surya, M. I. (2016). Current status of pre-breeding research involving wild species in Bogor and Cibodas Botanic Gardens. the international conference on pre-breeding and gene discovery (ICPGD). IAARD. (in press)

Medina, F. I. S., Amano, E., \& Tano, S. (2004). Mutation Breeding Manual. Forum for Nuclear Cooperation in Asia (FNCA). Japan Atomic Industrial Forum Inc. (JAIF). Japan. 177 pp.

Normasiwi, S., \& Surya, M. I. (2016). The Potential Fruit Crop of Cibodas Botanical Garden. Biosaintifika: Journal of Biology \& Biology Education, 8(2), 206-213.

Roychowdhury, R. \& Tah, J. (2011). Chemical mutagenic action on seed germination and related agro-metrical traits in M1 Dianthus generation. Current Botany, 2(8), 19-23.

Sharma, L.K., Kaushal, M., Gill, M.I.S., \& Bali, S.K. (2013). Germination and survival of Citrus jambhiri seeds and epicotyls after treating with different mutagents under in vitro conditions. Middle-East Journal of Scintific Research, 16(2), 250-255.

Surya, M. I., Ismaini L. \& Destri (2015). Keragaman Buah Raspberries (Rubus spp.) Asal Indonesia. Prosiding Seminar Nasional Biologi Tahun 2014. Universitas Negeri Semarang.

Suryana, N., \& Widyatmoko, D. (2013). Cibodas Botanic Garden at a glance. Technical Implementing Unit for Plant Conservation Cibodas Botanic Garden-Indonesian Institute of Sciences. Cianjur. Indonesia. $127 \mathrm{pp}$.

Umavathi, S., \& Mullainathan, L. (2014). Mutagenic effect of gamma rays and EMS on seed germination, seedling height reduction and survivability of Chick pea (Cicer arietinum L.) Var. Co -4. International Letters of Natural Sciences, 11(1), 3843. 